\title{
Mao Zedong in ContemporaryChinese Official Discourse andHistory
}

Arif Dirlik

\section{OpenEdition}

1 Journals

Electronic version

URL: http://journals.openedition.org/chinaperspectives/5852

DOI: 10.4000/chinaperspectives.5852

ISSN: 1996-4617

Publisher

Centre d'étude français sur la Chine contemporaine

\section{Printed version}

Date of publication: 4 June 2012

Number of pages: 17-27

ISSN: 2070-3449

\section{Electronic reference}

Arif Dirlik, "Mao Zedong in ContemporaryChinese Official Discourse andHistory », China Perspectives [Online], 2012/2 | 2012, Online since 30 June 2015, connection on 28 October 2019. URL : http:// journals.openedition.org/chinaperspectives/5852; DOI : 10.4000/chinaperspectives.5852 


\title{
Mao Zedong in Contemporary
}

\section{Chinese Official Discourse and}

\section{History}

ARIF DIRLIK ${ }^{(1)}$

\begin{abstract}
Rather than repudiate Mao's legacy, the post-revolutionary regime in China has sought to recruit him in support of "reform and opening." Beginning with Deng Xiaoping after 1978, official ${ }^{(2)}$ historiography has drawn a distinction between Mao the Cultural Revolutionary and Mao the architect of "Chinese Marxism" - a Marxism that integrates theory with the circumstances of Chinese society. The essence of the latter is encapsulated in "Mao Zedong Thought," which is viewed as an expression not just of Mao the individual but of the collective leadership of the Party. In most recent representations, "Chinese Marxism" is viewed as having developed in two phases: New Democracy, which brought the Communist Party to power in 1949, and "socialism with Chinese characteristics," inaugurated under Deng Xiaoping and developed under his successors, and which represents a further development of Mao Zedong Thought. The Hu Jintao leadership has made an aggressive effort to portray "Chinese Marxism" as the most advanced development of Marxism that might also serve as a model for others. These interpretive operations have salvaged Mao for the national revolution and the legitimacy of the Communist Party. But it also presents a predicament in keeping alive memories of Mao's policies, which the Party is not always able to control in political memory, as has been illustrated most recently in the Chongqing experiment.
\end{abstract}

KEYWORDS: Mao Zedong, Mao Zedong Thought, Deng Xiaoping, "Chinese Marxism," New Democracy, "socialism with Chinese characteristics".

M ao Zedong is once again back in the news. He was resurrected by Chongqing (重庆) Party Secretary Bo Xilai (薄熙来) around four years ago to lend cultural/ideological weight to the experiment Bo planned with a socialism that would combine Mao-style populist egalitarianism with tighter party-state control over the economy; this time within the context of global capitalism, of which the People's Republic of China (PRC) is an integral component, if not a motor force. The search for answers to apparent disagreements over Bo's recent dismissal by those suspicious of his challenge to the existing state-capitalism controlled by the Communist Party seems only to have intensified speculation over the strength of Maoism in the Party.

So deeply is Mao identified with the Cultural Revolution in contemporary consciousness that observers of recent developments rarely draw a distinction between a Mao revival and a cultural revolutionary revival. Symbolic it may have been, but Bo's revival of Red Culture was most importantly reminiscent of the Cultural Revolution, which despite some relaxation is still a taboo subject in the People's Republic of China. Whether or not it was directed at Bo, Premier Wen Jiabao's (温家宝) recent warning of a possible recurrence of the Cultural Revolution unless problems of development mainly political and economic inequality and corruption - were resolved offered a tacit recognition of at least one important reason for the anxiety that is usually ignored these days in discussions of the Cultural Revolution: the Cultural Revolution as an attack on the inequalities created by the Communist Party, whose reason for existence theoretically was to abolish inequality. ${ }^{(3)}$ To recall the Cultural Revolution if only symbolically is to draw attention to a problem that is far more severe at present than it was in the 1960s. And that is not permissible; talk of class difference and division has been largely silenced in the PRC as it has in other contemporary societies, and perhaps for more easily understandable reasons.

The same, however, is not the case with Mao - not the Mao of the Cultural Revolution but the Mao of the Chinese revolution and founding of the PRC. I argue in this essay that salvaging Mao from the Cultural Revolution to appropriate him for "socialism with Chinese characteristics" has been one of the strategic ideological concerns of the post-Mao leadership from Deng Xiaoping to the present. My analysis is based on the contemporary con-

1. I am grateful to Yige Dong, Sebastian Veg, Wang Guo, and Wu Yiching for reading and commenting on this essay. I am especially grateful to Sebastian Veg for helping me acquire the sources without which this essay would not have been possible. I am also grateful to an anonymous reader for China Perspectives for a careful reading and astute suggestions. These colleagues and friends helped enrich the argument but bear no responsibility for its shortcomings.

2. My use of "official" here needs some explanation, as it determines the coverage of the discussion. In some basic sense, all discourse and history in China is official, as both are closely watched and censored by the authorities. There is considerable leeway within limits, but the limits matter. The most important of such limitations are sensitive matters relating to leaders. I was personally acquainted with those limits when my book Anarchism in China was banned and collected almost immediately after its Chinese translation was published, apparently on the grounds that "it insulted our leaders." My use of "official" here is limited in coverage to officially-produced works that establish those official limits to interpretation that then provide a guide for permissible interpretation for society at large but most importantly for the Party - at least that is the intention. Also excluded from the discussion are works produced by officials after they have left office, some of whom have been quite harsh in their departures from the official line. For a brief but useful general survey of recent Mao scholarship, see Xiao Yanzhong, "Recent Mao Zedong Scholarship in China," in Timothy Cheek (ed.), A Critical Introduction to Mao, New York, Cambridge University Press, 2010, pp. 273-287.

3. "China's Wen Jiabao calls for 'urgent' political reform," The Telegraph, Thursday, 5 April 2012, http://www.telegraph.co.uk/news/worldnews/asia/china/9142333/China's-Wen-Jiabao-calls-forurgent-political-reform.html (consulted on 30 April 2012). 
struction of Communist Party history and its ideological articulation in a "Chinese Marxism," which are structured around a distinction between a Mao of the New Democratic Revolution and a Mao of the Cultural Revolution. These texts condemn Mao the Cultural Revolutionary but assign to the Mao of New Democracy a foundational historical role, and to Mao Zedong Thought a living historical significance as an expression of collective Party identity. The distinction is ideological, made possible by the denial of the history that links the two Maos. The texts point to a contradiction that may be essential to grasping the political and ideological dynamics of the Party. The appropriation of Mao for the reforms (to the point at the popular level of making him into an object of consumption) suggests the possibility of the return of the more radical Mao should the reforms run into trouble. This may very well be the significance of the Chongqing experiment, as well as what Wen Jiabao had in mind in his observations on a possible return of Cultural Revolution-type disorder. What Wen did not say was that the contradiction is inherent in the ideology that keeps Mao alive in the legitimation of the Party, therefore risking the return of the radical Mao should it lose its ability to sustain the distinction upon which it has gambled its ideological credentials. ${ }^{(4)}$ Being products of Party culture, Chinese leaders are quite aware of the risks, even if the same culture might hold them back from doing anything about it. ${ }^{(5)}$

\section{Reform and the re-invention of Mao Zedong Thought}

Contrary to the impression left by the radical transformations since 1978, the Chinese Communist Party has never officially repudiated Mao. Despite the demotion he has suffered over the past three decades in and out of the People's Republic of China, Mao Zedong continues to occupy a central place in official and officially sponsored histories of the Chinese Revolution, its past and present. Whatever personal feelings they may harbour, Chinese leaders officially propagate the line that the Communist Party continues the work that Mao started: to build a strong socialist state informed by a Marxism that has been adjusted to national circumstances in keeping with the demands of the times. As might be expected, they view this work as having gotten under way sometime in the 1930s, then having gone astray for more than two decades from the mid-1950s to the late 1970s with the left-extremism of the Cultural Revolution before being revitalised by his successors.

This official line has shown remarkable consistency since the post-Mao regime reversed the policies of the Cultural Revolution, although it has undergone elaboration and consolidation. Attitudes toward Mao have likewise undergone shifts among the public, along with what officialdom has deemed appropriate in celebrating Mao. But the basic line, and the justification given for it, has remained much the same.

Continued fealty to Mao's legacy despite the reversal of his radical policies may be attributed at the most obvious level to the legitimacy needs of the Communist Party. This no doubt is not far from the truth, but calls for more in-depth exploration for what it may have to say about the Party's ideological self-representation. The Party claims the mantle of the revolution. Given the prominent part Mao played in the revolution as its leader and chief theoretician, it would be rather a difficult task to uphold the historical significance of the revolution and its achievements while repudiating his legacies. The examples of Russia and Eastern Europe provide ample testimony of what happens to the legacies of socialist revolutions once their founding

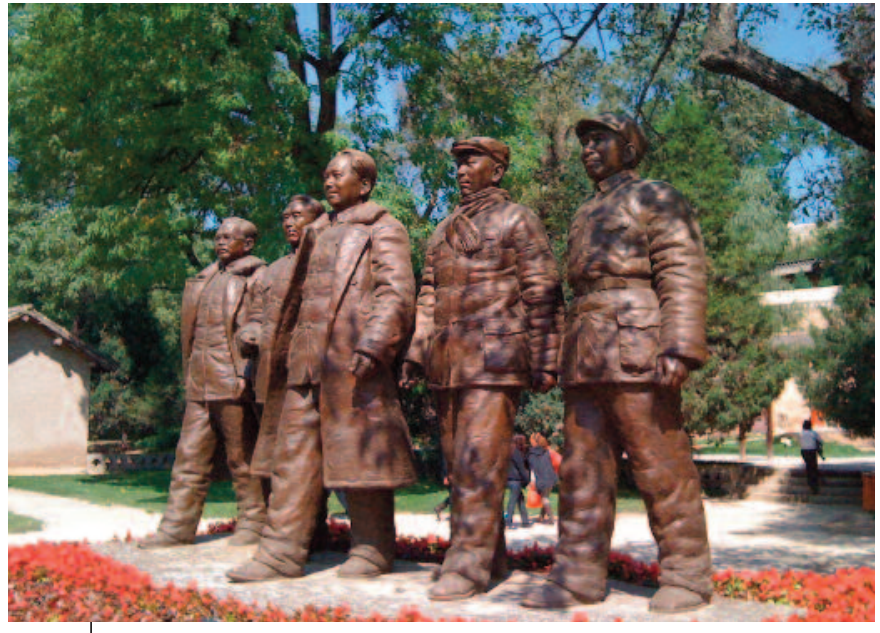

Bronze statue at Yangjia Ling, Yan'an of the five party leaders who set out from the Communist base at Yan'an to take power as New China's rulers.

(c) G.R. Barmé

leaders have been discredited. The post-Mao leadership in China has avoided this mistake despite, or perhaps because of, the upheaval it experienced during the Cultural Revolution in the 1960s, which made Party loyalty an overwhelming consideration. As Deng Xiaoping (邓小平) would warn in 1980, "When we write about his mistakes, we should not exaggerate, for otherwise we shall be discrediting Chairman Mao Zedong, and this would mean discrediting our Party and state." (6)

Deng himself would lead the effort to reconstruct Party history to appropriate Mao for the reforms. Representations of Mao in the PRC and abroad that are dominated by memories of the Cultural Revolution overlook that there is more than one Maoist legacy available to the Party in the legitimation of the revolutionary past: not only that of Mao the Cultural Revolutionary but also of Mao the leader of the national revolution who gave voice to the theoretical formulations of Marxism in defence of the pursuit of national aims: a "Chinese Marxism" growing out of the historical experience of the Chinese Revolution. The current leadership projects its own undertaking - and the 30 years of "reform and opening" under the successive

4. There is a resonance between my argument here and some of the contributions to the recently published (and suggestively titled) volume, Sebastian Heilmann and Elizabeth J. Perry (ed.), Mao's Invisible Hand:The Political Foundations of Adaptive Governance in China, Cambridge (MA), Harvard University Press, 2011. The contributors to this volume demonstrate the persistence of practices developed during the revolutionary years in contemporary political practices - from "guerrilla policy style" to mass campaigns to willingness to experiment and learn from experience. With the exception of one essay, the volume does not deal with issues of formal ideology, which is my concern here. It is also in the realm of ideology that the contradictions of the regime are most sharply visible.

5. In the 1980s, the distinguished literary critic coined the term "Mao style" to refer to a kind of writing that characterised Party discourse, whether or not the writer sought to emulate Mao. This "mechanical solidarity" may well be a manifestation of Party culture that persists. Frank Pieke is one scholar who has explored this Party culture, with its contemporary transformations as well as its persistence. See Frank Pieke, The Good Communist: Elite Training and State Building in Today's China, Cambridge, Cambridge University Press, 2009. For an interesting discussion of the persistence in language, see Zhao Yuezhi, "Sustaining and Contesting Revolutionary Legacies in Media and Ideology," in Perry and Heilmann, Mao's Invisible Hand, op. cit., pp. 201-236. Zhao argues that new public relations methods are superimposed on Maoist language and controls. For "Mao style," see Li Tuo, "Resisting Writing," in Liu Kang and Xiaobing Tang (ed.), Politics, Ideology and Literary Discourse in Modern China: Theoretical Interventions and Cultural Critique, Durham (NC), Duke University Press, 1993, pp. 273-277.

6. Deng Xiaoping, "Remarks on Successive Drafts of the 'Resolution on Certain Questions in the History of Our Party Since the Founding of the People's Republic of China"' (hereafter, "Drafts"), in Selected Works of Deng Xiaoping, 1975-1982 (hereafter, SWDXP), Beijing, Foreign Languages Press, 1984, pp. 276-296, p. 287. 
leaderships of Deng Xiaoping and Jiang Zemin (江泽民) (but not Hu Yaobang 胡耀邦 and Zhao Ziyang 赵紫阳) - as further developing the policies of New Democracy that brought the Communist Party to power in 1949 under Mao's leadership. In this historical reconstruction, "socialism with Chinese characteristics" (中国特色社会主义) as formulated by Deng Xiaoping and enriched by his successors represents a second stage in the unfolding of "Chinese Marxism," of which New Democracy (新民主主义) under Mao was the inaugural phase. The Cultural Revolution, sandwiched in between, serves in the new history of "Chinese Marxism" as a period when the ideology went astray (and a "negative example" from which to learn what not to do), but it leaves Mao's "true" legacy intact for his successors to follow up on once this temporary deviation had been overcome.

The reinterpretation of Mao's "correct" thought was especially important at the beginning of the reform period, when there still were Maoists powerful and popular enough to torpedo an abrupt reversal of the policies of the Cultural Revolution and the ideological orientation that had guided them. This consideration would gradually fade after the Tiananmen tragedy of 1989. As reforms gained speed in the 1990s, now stimulated by a new awareness of globalisation, Mao was no longer the threat he had been earlier, as suggested by the regime's mostly tolerant response to the "Mao fever" (Mao Zedong re 毛泽东热) that accompanied the celebration of the $100^{\text {th }}$ anniversary of Mao's birth in 1993. It was also right around this time that a serious rewriting of the first three decades of PRC history got underway, culminating in the Party history published only last year, in time for the $90^{\text {th }}$ anniversary of the Party's founding. ${ }^{(7)}$ This history, and works on Chinese Marxism that have appeared only during the last two or three years, have brought into focus an interpretive effort that traces its origins to the reforms that put an end to Mao's radical policies.

Mao, it may be recalled, was never officially repudiated. Indeed, the overthrow of the "Gang of Four," the termination of the Cultural Revolution, and the turn to "reform and opening" with the historic Third Plenary Session of the Eleventh Central Committee in December 1978 were viewed by the Party leaders as the restoration of "the correct path of Marxism-Leninism and Mao Zedong Thought." (8) "Marxism-Leninism and Mao Zedong Thought" were enshrined in 1979 as one of the four "cardinal principles" guiding the Party (in addition to "the socialist road," "dictatorship of the proletariat," and "leadership of the Communist Party"). The final verdict would be provided in the "Resolution on certain questions in the history of our party since the founding of the People's Republic of China" (hereafter, 1981 Resolution), which was endorsed by the Sixth Plenary Session of the $11^{\text {th }}$ Central Committee in late June 1981. (9) This document, and the discussions that attended it, were in hindsight among the foundational documents of "socialism with Chinese characteristics." (10) Supplemented by pronouncements from Jiang Zemin and Hu Jintao (胡锦涛) whose policies are viewed as further developments of Chinese Marxism, they have served as a template for writing the history of Marxism in China - and Mao into that history.

The 1981 Resolution held Mao directly responsible for the leftist errors of the Cultural Revolution, but concluded nevertheless:

Comrade Mao Zedong was a great Marxist and a great proletarian revolutionary, strategist and theorist. It is true that he made gross mistakes during the "cultural revolution," but if we judge his activities as a whole, his contributions to the Chinese revolution far outweigh his mistakes. His merits are primary and his errors secondary. He ren- dered indelible meritorious service in founding and building up our Party and the Chinese People's Liberation Army, in winning victory for the cause of liberation of the Chinese people, in founding the People's Republic of China, and in advancing our socialist cause. He made major contributions to the liberation of the oppressed nations of the world and to the progress of mankind. (11)

Deng Xiaoping's account of the successive drafts of the 1981 Resolution leaves little question that this conclusion was reached after considerable disagreement and deliberation within the Party. (12) How the "Resolution" manoeuvred its way through the Cultural Revolution, weighed Mao's errors against his achievements, and balanced the mistakes of the Cultural Revolution against past achievements has been discussed by other scholars. ${ }^{13)}$ What is of interest in the document for our purposes here is its historical delineation of Mao as the Party's leader, and its relationship to Mao Zedong Thought and Chinese Marxism. Mao Zedong's achievements as leader from the mid-thirties to the mid-fifties were indisputable. He had led the Party to victory in the New Democratic Revolution, opened up a new historical era by liberating China, and overseen the transition to socialism completed by 1956. Even after his radical left-turn shortly after the Eighth Party Congress in 1956, he had continued to make important contributions to China's development right through the Cultural Revolution, when his mistakes were at their most destructive. Throughout, he had continued to produce theo-

7. Zhonggong zhongyang dangshi yanjiushi (中共中央党史研究室) (CCP Central Party History Office), Zhongguo gongchandang lishi (中国共产党历史, History of the Chinese Communist Party), 2 vols., Beijing, Zhongyang dangshi yanjiushi, vol. 1, 2002 / vol. 2, 2011. The first volume, edited by Hu Sheng (胡绳) and Hu Qiaomu (胡乔木), was based with revisions on a 1991 volume of the same title covering the years before 1949. It was published as a two-part set, covering respectively 1921-1937 and 1937-1949. In addition to new materials utilised, its main revisions were prompted by post- 1991 speeches by Deng Xiaoping and, more significantly, the new leader Jiang Zemin's "important thought of 'three represents."' (see "Afterword," Part 2, pp. 1051-1055). The second volume of 2011 was also published as a two-volume set, each roughly 500 pp. covering, respectively, the years 1949-1958 and 1958-1978. See the interview with a former vicedirector of the Office, Zhang Qihua (张启华), who oversaw successive revisions of the text, in Zhongguo xinwen zhoukan (中国新闻周刊) (China News Weekly), excerpted in "Zhonggong dangshi chengren sannian ziran zaihai 1000 duo wan ren siwang” (中共党史承认三年自然害灾 1000 多万人死亡, CPC Party History acknowledges deaths of more than 10 million during the 3year natural disaster), Cenews.eu, 14 January 2011, http://www.cenews/?p=28441 (consulted on 8 May 2012). Hereafter, Zhang Qihua.

8. Deng Xiaoping, "Uphold the Four Cardinal Principles" (30 March 1979), in SWDXP, pp. 166-191, p. 167.

9. "Resolution on certain questions in the history of our party since the founding of the People's Republic of China" (hereafter, Resolution), adopted on 27 June 1981, Chinese Communism Subject Archive, http://www.marxists.org/subject/china/documents/cpc/history/01.htm (consulted on 30 April 2012).

10. In an essay published in 1986, Brantly Womack suggested that the 1981 Resolution was comparable in significance to a similar document produced in 1945, "Resolution on Certain Questions in the History of Our Party." The latter provided an account of the Party's history since 1921, foregrounding the role of Mao, who in the Seventh Party Congress in 1945 was anointed undisputed leader of the Party and emblem of Mao Zedong Thought. The 1981 Resolution, which in its concluding paragraph did indeed refer to the 1945 Resolution as its antecedent, laid the groundwork for the writing of Party history for the 1949-1978 period. Womack's suggestion is confirmed in recent historical work, which consistently refers to this document as a primary guideline. See Brantly Womack, "Where Mao Went Wrong: Epistemology and Ideology in Mao's Leftist Politics," The Australian Journal of Chinese Affairs, no. 16, July 1986, pp. 23-40. In his speech on the occasion of the 90th anniversary of the founding of the CCP on 1 July 2011, Hu jintao once again referred to the two resolutions as storehouses of the Party's "experiences and lessons." Hu Jintao, "Speech at CPC Anniversary Gathering," http://news.xinhuanet.com/english2010/china/201107/01/c_13960505_6.htm (consulted on 30 April 2012), 17 pages, p. 6.

11. "Resolution," p. 34

12. Deng, "Drafts," is an invaluable testament to inner-Party negotiation in producing this important document. As I shall note below, the Party history published 30 years later went through similar negotiation, this time extending over 15 years!

13. Womack, "Where Mao Went Wrong," op. cit:; John Bryan Starr, "'Good Mao', 'Bad Mao': Mao Studies and the Re-Evaluation of Mao's Political Thought," The Australian Journal of Chinese Affairs, no. 16, July 1986, pp. 1-6; Nick Knight, "The Form of Mao Zedong's 'Sinification' of Marxism," The Australian Journal of Chinese Affairs, no. 9, January 1983, pp. 17-33. 
retical work that was quite significant in contributing to socialist reconstruction. As the quotation above indicates, there was no questioning his role as the leader of the Chinese Revolution.

The most interesting part of the 1981 Resolution related to Mao Zedong Thought. The "Resolution" reaffirmed the distinction between Mao's thought and the Mao Zedong Thought that had been part of Party ideology since the origins of that formulation in the early 1940s. ${ }^{(14)}$ One referred to the thinking of an individual leader, the other to the crystallisation of the collective wisdom of the Party's revolutionary experience as articulated by the leader of the Party. What it had to say is worth quoting at some length because of its implications not only for placing Mao in the ideological reconstruction in the past, but also for the part Mao Zedong Thought would play in the unfolding of "socialism with Chinese characteristics":

The Chinese Communists, with Comrade Mao Zedong as their chief representative, made a theoretical synthesis of China's unique experience in its protracted revolution in accordance with the basic principles of Marxism-Leninism. This synthesis constituted a scientific system of guidelines befitting China's conditions, and it is this synthesis which is Mao Zedong Thought, the product of the integration of the universal principles of Marxism-Leninism with the concrete practice of the Chinese revolution. Making revolution in a large Eastern semi-colonial, semi-feudal country....cannot be solved by reciting the general principles of Marxism-Leninism or by copying foreign experience in every detail. The erroneous tendency of making Marxism a dogma and deifying Comintern resolutions and the experience of the Soviet Union prevailed in the international communist movement and in our Party mainly in the late 1920s and early 1930s, and this tendency pushed the Chinese revolution to the brink of total failure. It was in the course of combating this wrong tendency and making a profound summary of our historical experience in this respect that Mao Zedong Thought took shape and developed. It was systematized and extended in a variety of fields and reached maturity in the latter part of the Agrarian Revolutionary War and the War of Resistance Against Japan, and it was further developed during the War of Liberation and after the founding of the People's Republic of China. Mao Zedong Thought is Marxism-Leninism applied and developed in China; it constitutes a correct theory, a body of correct principles and a summary of the experiences that have been confirmed in the practice of the Chinese revolution, a crystallization of the collective wisdom of the Chinese Communist Party. ${ }^{(15)}$

The identification of Mao Zedong Thought with the collective wisdom of the Party rather than Mao the individual suggested not only that it was possible for Mao, the leader, to transgress against Mao Zedong Thought, but also that Mao Zedong Thought was a work in progress, "still in the process of development" after the passing of Mao, the leader. ${ }^{(16)}$ There was a danger here, too, that the Party might be culpable for the wrong turn that the ideology had taken during the two decades of deviation, which was indeed conceded by the document. ${ }^{(17)}$ On the other hand, Mao Zedong Thought as the expression of the collective leadership of the Party has been elevated to a plane where it leads an unblemished existence beyond the errors of individual leaders, having demonstrated repeatedly its ability to correct its mistakes. Making mistakes was inevitable for living people, Mao himself had stated in 1945, adding that only the unborn and the dead don't make mis- takes. He had admitted to the many mistakes he and others (including Marx and Engels) had made in the course of revolutionary activity. But when Mao Zedong Thought was enshrined in the Seventh Party Congress of that year, those mistakes were excluded. Likewise in the present the mistakes Mao had made in his later years must be excluded from Mao Zedong Thought to preserve the latter's status as the infallible guide to socialist reconstruction. ${ }^{(18)}$

To recall a distinction Franz Schurmann has drawn in his study of ideology in the PRC, Mao Zedong Thought is given an abstract existence and a longevity in these discussions that raises it almost to the status of an "ideology" of universal significance rather than a "thought" that represents the concrete practice of the ideology. ${ }^{(19)}$ As the 1981 "Resolution" framed it:

Mao Zedong Thought is the valuable spiritual asset of our Party. It will be our guide to action for a long time to come.... While many of Comrade Mao Zedong's important works were written during the periods of new-democratic revolution and of socialist transformation, we must still constantly study them. This is not only because one cannot cut the past off from the present and failure to understand the past will hamper our understanding of present-day problems, but also because many of the basic theories, principles and scientific approaches set forth in these works are of universal significance and provide us with invaluable guidance now and will continue to do so in the future.... Mao Zedong Thought has added much that is new to the treasure-house of Marxist-Leninist theory. We must combine our study of the scientific works of Comrade Mao Zedong with that of the scientific writings of Marx, Engels, Lenin and Stalin. ${ }^{(20)}$

The greatest achievement of Mao Zedong Thought was its integration of universal Marxist theory and concrete Chinese practice. In 1980, Deng Xiaoping insisted that "it is precisely Mao Zedong Thought that the present Central Committee upholds, only we have given it concrete content." (21) The statement elevates Mao Zedong Thought to an ideological plane comparable to that of Marxism-Leninism, but at the same time evacuates it of any substantial content, which also increasingly has come to characterise the rela-

14. See, Raymond F. Wiley, The Emergence of Maoism: Mao Tse-tung, Ch'en Po-ta and the Search for Chinese Theory, 1935-1945, Stanford (CA), Stanford University Press, 1980.

15. "Resolution," pp. 34-35

16. Deng, "Drafts," in SWDXP, op. cit., p. 282. The "Resolution" stated that the "erroneous 'Left' theses, upon which Comrade Mao Zedong based himself in initiating the "cultural revolution," were obviously inconsistent with the system of Mao Zedong Thought, which is the integration of the universal principles of Marxism-Leninism with the concrete practice of the Chinese revolution," p. 19.

17. See also Deng, "Drafts," p. 281

18. Zhonggong zhongyang dangshi yanjiushi yishi (ed.), 'Zhongguo gongchandang lishi (shangjuan)' ruogan wenti shuoming" ("中国共产党历史[上卷]若干问题说明 Explaining some questions in the first volume of the History of the Communist Party of China), Beijing, Zhonggong dangshi chuban she, 1991, pp. 211-213. This interesting volume, published as a companion volume to the Party history published in 1991, was devoted to clarification of unresolved problems in the History. The clarifications were used also to comment on contemporary issues. In addition to this explication of the relationship between Mao and Mao Zedong Thought, the volume also drew attention to the Communist Party's struggles with bourgeois thinking in the 1920s, and its parallels with the struggles against advocates of bourgeois economics and politics since the beginning of Reform and Opening (pp. 20-21). See also Mei Rongzheng (梅荣政, chief editor), Makesizhuyi Zhongguohua shi (马克思主义中国化史 History of making Marxism Chinese), Beijing, Social Sciences Publication Press, 2010, p. 633, where the author cites Deng Xiaoping to the effect that "Mao Zedong's mistakes late in life do not belong to Mao Zedong Thought."

19. Franz Schurmann, Ideology and Organization in Communist China, new enlarged edition, Berkeley (CA), University of California Press, 1968, esp. pp. 24-58.

20. "Resolution," op. cit., p. 45.

21. Deng, "Drafts," in SWDXP, op. cit., p. 283. 
tionship of Chinese Marxism to Marxism. The development of the Chinese Communist Party beginning with Mao's leadership in the 1930s has become at one and the same time the historical unfolding of "Chinese Marxism," with ever fewer references to the theoretical sources it claims as its ancestral origins. In other words, its Marxism has become increasingly self-referential. (22) In addition to the example it provided in the appropriate handling of Marxism in the national revolution, the reaffirmation of Mao Zedong Thought under Deng Xiaoping had a second, more concrete, significance. Mao Zedong Thought was formulated and reached its fullness in the course of the New Democratic revolution, of which it was the ideological expression. Hence its evocation also invoked the question of the relevance of its policies following the elimination of the leftist zeal of the Cultural Revolution. I have suggested elsewhere that there was much in common initially between reform policies after 1978 and policies of New Democracy that had brought the Communist Party to power: a coalition government under the leadership of the Communist Party and the "dictatorship of the proletariat"; a mixed economy blending private national capital and state management and direction (bureaucratic capital); and a culture policy that sought to integrate a new Communist culture with native legacies, especially popular culture. (23) Theoretically speaking, reforms after 1978 picked up where the Eighth Conference in 1956 had left off, when the transition to socialism had been completed. As the 1981 Resolution stated in the section just quoted, however, while New Democracy belonged to an earlier phase of the revolution, it was the foundation of Mao Zedong Thought, and its documents would retain their significance for the foreseeable future. It is quite clear in hindsight that the reforms initiated in the 1980s would ultimately go back past 1956 to the mixed policies of New Democracy, especially in economic policy. Cultural policy has abandoned Mao's stress on popular culture as the source of a new culture except in its more theatrical forms, and there has been a revival of elite traditions reminiscent of Kuomintang (guomindang 国民党) policies in the 1930s. It is only in the consolidation of Communist Party rule and "the dictatorship of the proletariat" (albeit independently of the latter) that reform policies would go beyond the provisions of the 1956 conference. In an essay published in 1999, the distinguished historian Hu Sheng (head of the Chinese Academy of Social Sciences between 1985 and 1998) pointed out that New Democracy was very important for understanding "socialism with Chinese characteristics." (24) Hu at the time (until his death in 2000) was also in charge of the group working on the official History of the Chinese Communist Party since 1949 published last year. ${ }^{25)}$

The re-evaluation of Mao Zedong Thought in 1980-1981 set the stage for the part Mao was to play in official historiography since then. It is worth stressing here two dimensions of this re-evaluation. On the one hand, Mao Zedong Thought was associated intimately with the policies of New Democracy that had prevailed for two decades between the mid-thirties and the mid-fifties, and therefore belonged to the past of the Party. On the other hand, as the foundation for a Chinese Marxism that would continue to develop for the foreseeable future, Mao Zedong Thought transcended its times, and lived on in Party ideology as a guide to the future of socialism. In his ninetieth anniversary speech in 2011, Hu Jintao reiterated this double temporality of Mao Zedong Thought when he stated:

The Party has consistently integrated the basic tenets of Marxism with the specific conditions of China, and it has made two great theoretical achievements in the historical process of adapting Marxism to China's conditions. One is Mao Zedong Thought, which represents the application and development of Marxism-Leninism in China. Mao Zedong Thought has resolved in a systematic way the issue of how to accomplish the new-democratic revolution and socialist revolution in China, a big semi-colonial and semi-feudal country in the East, and made painstaking effort to explore the issue of what kind of socialism China should build and how to build it, thereby making new and creative contributions to enriching Marxism. The other theoretical achievement is the system of theories of socialism with Chinese characteristics. This is a scientific theoretical system consisting of Deng Xiaoping Theory, the important thought of Three Represents, the Scientific Outlook on Development and other major strategic thoughts.... The system of theories of socialism with Chinese characteristics represents the continuation and development of Mao Zedong Thought. (26)

Mao Zedong Thought represented the integration of Marxist theory with the concrete practice of the Chinese revolution. It was not merely the application of Marxism to the Chinese revolution, but also added "new content" (xinde neirong 新的内容) to Marxism and enriched it theoretically. (27) Reference to Marxism has remained as a basic tenet of the Party's practice, but Mao Zedong Thought itself has come to represent "a new stage of Marxism" for the Party to refer back to as a theoretical basis for practice in the new circumstances that it faced. It is worth noting also that however strenuously the Party sought to distinguish between Mao and Mao Zedong Thought, it could not (or would not) take Mao the person out of the thought so long as it insisted on that particular formulation.

\section{Mao in official historiography}

Over the last three decades, official histories of the revolution have followed closely the line established in the 1981 Resolution. The editors of a

22. For a cogent summary of the ideological process from the origins of Mao Zedong Thought to Hu Jintao, see Zhiyue Bo, "Hu Jintao and CCP's Ideology: A Historical Perspective," Journal of Chinese Political Science, vol. 9, no. 2, Fall 2004, pp. 27-45. Bo suggests that with Hu Jintao ideology has become "an asset" of the Party, with the Party Secretary as its institutional interpreter. So far, we might add, the process has been cumulative, with each Secretary referring to and building on the previous interpretation - in other words, filling in new content as circumstances dictate, with only symbolic gestures toward theory. For a discussion of successive leaders' contribution to theory, see Xiao Dongbo (肖东波) and Nie Yueyan (聂月岩), et al., Zhongguo gongchandang lilun jianshede lishi jingyan yanjiu (中国共产党理论建设的历史经验研究 Investigation of the historical experience of the Chinese Communist Party in theory building), Beijing, Party Building Reading Materials Publishers, 2005, Introduction, Pp. 1-12. This work, written at the beginning of the Hu jintao leadership, is mostly an elaboration of Jiang Zemin's contributions. It also suggests that the systematisation (xitonghua 系统化) and institutionalisation (zhiduhua 制度化) of theory production got underway in earnest with the Jiang leadership.

23. Arif Dirlik, "Mao Zedong and 'Chinese Marxism,"' in Arif Dirlik, Marxism in the Chinese Revolution, Lanham (MD), Rowman \& Littlefield, 2005, pp. 75-104, and, "Back to the Future: Contemporary China in the Perspective of Its Past, circa 1980," boundary 2, vol. 38, no. 1, Spring 2011, pp. 7-52. The inspiration of New Democracy also links the reforms to Sun Yat-sen's ideas on Chinese economic development, as New Democracy was very much entangled in ideological competition with the Kuomintang to appropriate Sun Yat-sen for the Communist Party. For a recent discussion, see Huang Zhigao (黄志高), Sanminzhuyi lunzhan yu Makesizhuyi Zhongguohua (三民主义论 战与马克思主义中国化The controversy over the Three Peoples Principles and making Marxism Chinese), Beijing, Shifan daxue chuban she, 2010.

24. Hu Sheng, "Mao Zedong de xinminzhu zhuyilun zai pingjia"(毛泽东的新民主主义论再评价 Re-evaluation of Mao Zedong's "On New Democracy"), Zhongguo shehui kexue, no. 3, May 1999, pp. 4-19.

25. Zhongguo gongchandang lishi, vol. 2, "Afterword," op. cit., pp. 1070-1074.

26. Hu Jintao, "Speech at Anniversary Gathering," op. cit., p. 4.

27. Guo Dehong (郭德宏, chief editor), Zhongguo Makesizhuyi fazhan shi (中国马克思主义发展史 History of the development of Chinese Marxism), Beijing, Central Party School Publications, 2010, preface, p. II. 
three-volume Party history written for the required course on MarxismLeninism at the Party School, published in 1990 (preface dated 1987), wrote:

This book follows the correct line established at the Third Plenary Session of the Eleventh Central Committee, and has been written according to the spirit of "The Resolution on Certain Questions in the History of Our Party since the Founding of the People's Republic of China" at the Sixth Plenary Session of the Eleventh Central Committee. It applies the viewpoints of dialectical and historical materialism, is based on historical facts, and seeks truth from facts. (28)

Ideological requirements in the composition of Party history would become more complicated in ensuing years with the addition to Deng Xiaoping's "theory" of Jiang Zemin's "important thought of 'Three Represents'" ("三个代表”重要思想) and Hu Jintao's "scientific outlook on development" (科学发展观), but the basic line has remained unchanged. The first volume of the most recent official Party history published in 2002 reiterated its faithfulness to the same principles, but added to it jiang Zemin's take on the revolution. The second volume published in 2011 additionally bears the stamp of $\mathrm{Hu}$ Jintao. But since every leader has reaffirmed the 1981 Resolution as a fundamental document of reform, the Resolution has been basic to their evaluations of the past as well. Zhang Qihua pointed to the 1981 Resolution as the primary guide to the writing of the second volume of the Party history published in 1911. In the words of the editors, the guiding principles in writing the volume were:

Marxism-Leninism, Mao Zedong Thought, Deng Xiaoping Theory, the important thought of "Three Represents," deep and comprehensive pursuit of the scientific outlook on development, grasping important historical questions on the basis of the "Resolution on Certain Questions in the History of Our Party Since the Founding of the People's Republic of China," decisions of important meetings of the Party, and important directives of leading comrades of the Party Centre. (29)

The guidance was not just theoretical. While all officially sanctioned work acknowledges an arduous production process, this volume was particularly significant because of the sensitive issues it addressed of the post-New Democracy turn to the left in the transition to socialism and its culmination in the Cultural Revolution. It took nearly two decades to complete. Work on it began immediately after the publication in 1991 of volume 1 (subsequently revised for republication in 2002), (30) which covered the period from the founding of the Party in 1921 to the victory of New Democracy in 1949. According to the editor's account, it was vetted repeatedly by relevant scholars and Party leaders, and went through numerous revisions before it was finally approved for publication in 2011, in time for the Party's ninetieth anniversary. ${ }^{(31)}$

These works are based on documentation not available to outsiders. What they have to say about specific historical matters in Mao's life and activities may be taken up by specialists on those matters. What is of interest here is the delineation of Mao's place in the revolution and Chinese Marxism. Beginning with the 1981 Resolution to the production of the histories of the revolution and the Communist Party, a generally accepted periodisation of the revolution has come into focus: a New Democratic phase when Mao played a leading role in coalition politics, economic flexibility, and military strategy as "representative" (daibiao 代表) ${ }^{(32)}$ of the collective leadership of the Party; a Cultural Revolution phase (of over two decades) when Mao's leftist inclinations toward hasty development, socialist purity, and class struggle led the revolution astray; and a third phase when, under the successive leaderships of Deng Xiaoping, Jiang Zemin, and Hu Jintao, a regime of "socialism with Chinese characteristics" was established to guide the country through the initial phase of socialism, which is likely to last over a century. ${ }^{(33)}$

This periodisation is evident with greatest clarity in discussions of Mao Zedong Thought. A recently published volume, ${ }^{(34)}$ also intended as a textbook for the required course on Marxism at the Party School, organises the development of Chinese Marxism in two stages, with the first stage serving as the foundation for the second: New Democracy from the mid-thirties to the mid-fifties, with Mao as its moving spirit, and "socialism with Chinese characteristics," theorised most importantly by Deng Xiaoping after 1978 but with subsequent accretions. Mao Zedong Thought, the emblem of Chinese Marxism and the product of the Party's revolutionary practice, emerged during the first period in the Party's integration of Marxism-Leninism with the concrete realities of revolutionary practice in "semi-feudal semi-colonial" Chinese society. It was not merely an application of theory to Chinese society; it opened up a new theoretical vista on Marxism in economically and politically backward societies suffering from colonialist aggression. (35) Mao Zedong Thought was betrayed during the Cultural Revolution by Mao himself, when in his left turn he began to ignore the circumstances of Chinese society, broadened the scope of class struggle, and turned the masses against the Party. ${ }^{(36)}$ Mao nevertheless continued to make contributions to Mao Zedong Thought in the areas of development and international relations. It was most importantly the Party and the people, however, who kept it alive, and restored it to its rightful place after 1978. The restoration of the correct line of Mao Zedong Thought was accompanied by a second

28. Li Jianwei (李践为, chief editor), Zhongguo gongchandang lishi (History of the Chinese Communist Party), 3 volumes, Beijing, People's Publishing House, 1990, preface, p. 1. The volumes cover, respectively, 1919-1937, 1937-1949, and 1949-1956.

29. Zhang Qihua, "Interview," Zhongguo gongchandang lishi, vol. 2, op. cit., p. 1070.

30. See fn. 7 .

31. Zhang Qihua, op. cit., pp. 1071-1073. Even then, according to Zhang Qihua, the investigators were not allowed access to all records.

32. "Representative" is the preferred term in describing Mao throughout the period of New Democracy lasting through 1952. See "The basic overall conclusion on the Party during the period of New Democracy," Zhongguo gongchandang lishi (1990), vol. 2, pp. 436-445.

33. Guo Dehong (chief editor), Zhongguo Makesizhuyi fazhanshi (History of the development of Chinese Marxism), op. cit., p. 384.

34. Ibid. It is important that the usage in the title of the book, "Chinese Marxism," has become prevalent in recent years, pointing to a new attitude toward Marxism. That this is the intended use is indicated in the title of chapter 3, which juxtaposes "Marxism in China" (Makesizhuyi zai Zhongguo 马克思主义在中国) with "Chinese Marxism" (Zhongguo Makesizhuyi 中国马克思主义). I will say more on this below by way of conclusion. As for periodisation of Mao Zedong Thought (or Chinese Marxism), some texts do insert a third phase, "the transition to socialism" (1952-1956), but it is commonly accepted that New Democracy and "socialism with Chinese characteristics" represent ideological "great leaps." The transition is treated quite understandably more like a closure on New Democracy that was prematurely aborted. As Mao began to turn to the left in response to the contradictions created by New Democracy, the "transition," expected to continue for at least 15-20 years, quickly began to take a radical direction that would eventuate in the Great Leap Forward and the Cultural Revolution The interpretation does not refer to these contradictions, instead attributing the turn to the beginnings of Mao's erroneous tendencies.

35. Guo Dehong (Zhongguo Makesizhuyi fazhan shi, p. 382) and Song Shichang and Nong Fang (宋 士昌 and 农芳, Makesizhuyi Zhongguohua tonglun, 马克思主义中国化通论 A comprehensive discussion of making Marxism Chinese, 2 volumes, Jinan, Shandong People's Publication Press, 2010, p. 23) also emphasise the influence of the New Democratic Revolution and Mao Zedong Thought around the world. I think it would be more accurate to say that it was more the Cultural Revolution and the radical Mao that brought attention to the Chinese Revolution in the then Third World.

36. Guo Dehong, op. cit., chapter 12. 
"great leap" in Chinese Marxism equal in significance to the emergence of Mao Zedong Thought that produced "socialism with Chinese characteristics," beginning with Deng Xiaoping's theory and proceeding through Jiang Zemin's "Three Represents" and Hu Jintao's scientific outlook on development. It remains a work in progress in "the continuation and development of Mao Zedong Thought." (37)

This interpretation of Mao in the history of the revolution is a far cry from that of the Cultural Revolution, which had rendered Mao "the helmsman" of the revolution, and class struggle the core principle of Mao Zedong Thought (and Marxism). If Mao Zedong comes anywhere close under the new historical regime to the revolutionary sagacity attributed to him earlier, it is for the first phase of the revolution before 1949. Even then, the emphasis currently is on Mao "the representative" of the Party, who kept class struggle in moderation and recognised the significance of the forces of production to keep the revolution moving forward. At the same time, Mao is now held to account for what happened during the Cultural Revolution. Volume 2 of the History of the Communist Party of China, and a number of officially-sanctioned works on Chinese Marxism and Mao Zedong Thought published during the last couple of years, usually under the rubric of Makesizhuyide Zhongguohua (making Marxism Chinese), have broken the taboo on the discussion of the Cultural Revolution now that some agreement has been reached in the Party over the appropriate verdict that does the least damage to the Party. ${ }^{(38)}$ Previous histories, such as the 1990 history mentioned above, either stopped short of the turn to the left in the late 1950s, or simply blanked out the period between 1952 and 1978, as in the film produced on the occasion of the Fiftieth Anniversary of the Founding of the People's Republic in 1999 or in the current historical display at the New Museum of National History.

The gap is now being filled through historical work more open to confronting sensitive issues in the Party's past. What is genuinely new in these recent texts is not so much the overall interpretation, which largely follows the decisions of the 1981 Resolution, but the discussion in some detail of the period from the mid-1950s to 1978, and Mao's leading role in the developments surrounding the Cultural Revolution. Mao, the individual, does not fare well in this account, although criticism of his "left-deviation" after 1952 is much more measured than that to be found in some of the more incriminating works published outside of China. Beginning with the "transition to socialism" after 1952, Mao began to ignore the circumstances of Chinese society that were nowhere close enough to fulfilling the conditions for socialism, but also wrongly shifted emphasis in his reading of Marxism from the primacy of the forces of production to continued class struggle. His anxieties about capitalist restoration led to the persecution of so-called "revisionists," inflicting immense harm on the Party. In the verdict of the new Party history:

As the important leader of the Party and the state, Mao Zedong cannot but bear the major responsibility for the serious and comprehensive errors of "the cultural revolution." The power of the Party was excessively concentrated in one person, Mao Zedong's erroneous "leftist" leadership replaced the collective leadership of the Party, and the worship of the individual reached an insane level, undermining the possibility of the Party and the state to prevent and control the initiation and development of "the cultural revolution." (39)

The authors continue to observe, nevertheless, that the perpetuation of the Cultural Revolution for ten years provides prima facie evidence that it should not be blamed solely on one individual. Not only did many in the Party support Mao's line, but so did the people at large, who were still under the sway of the feudal practices of the past.

This is indeed the general approach to the evaluation of Mao Zedong in recent histories: he was responsible for what happened, but the responsibility must be shared by others, including other leaders in the Party. This was the case also with the communisation and Great Leap Forward movements of 1958-1960, which are officially acknowledged for the first time to have cost more than ten million lives. As the Party history puts it:

In launching "the great leap forward," Mao Zedong's hope initially was to change as quickly as possible the visage of poverty and backwardness, and to truly advance and strengthen China to establish its place among the world's nations. This was at one with the hopes prevalent among large numbers of cadres and the people. The problem was that it went against the line of seeking truth from facts that the Party promoted...exaggerated the uses of subjective will and effort, advocated leap-frogging over historical stages in purpose and policy, and created in practical work a situation that went against natural and economic laws. This kind of hot-headedness was not restricted to Mao Zedong; it was a prevalent attitude among central leaders and many cadres... ${ }^{(40)}$

If others shared in Mao's errors, Mao himself was not completely given to the leftist line he had let loose, but made repeated efforts to correct his mistakes - as in the retreat from the communes after 1960, his purge of Lin Biao (林彪), his criticism in the 1970s of Jiang Qing (江青), and the move forward during the same decade to a moderate modernisation program ("The Four Modernizations"). China had registered economic and technological achievements during the Cultural Revolution, and there were important achievements in foreign relations. Mao continued to contribute to these advances through his theoretical writings. The greatest credit for these achievements must nevertheless go to the Party and the people who preserved their loyalty to Mao Zedong Thought against all adversity. ${ }^{(41)}$

Admitting the Party's spiritual and political complicity in Mao Zedong's policies is, from everything we know, true to the spirit and the politics of the times, but that does not make it easily acceptable to those who suffered from his policies personally, or to those who for one reason or another would discredit Mao. The latter probably were the ones Deng Xiaoping in

37. Hu Jintao, "Speech at the CPC Anniversary Gathering," op. cit., p. 4.

38. Guo Dehong, Zhongguo Makesizhuyi fazhanshi, op. cit:; Song Shichang and Nong Fang (chief editors), Makesizhuyi Zhongguohua tonglun, op. cit:; Mei Rongzheng, Makesizhuyi Zhongguohua shi, op. cit.; Bi Guoming and Xu Luzhou (毕国明 and 许鲁洲), Zhongguo zhexue yu Makesizhuyi zhexue Zhongguohua (中国哲学与马克思哲学中国化 Chinese philosophy of making Marxist philosophy Chinese) Beijing, People's Publication Press, 2010. I have explained elsewhere why I think "making Marxism Chinese" is a better translation for Zhongguohua than the conventional term "sinicisation," with its traditionalist "China-centred" assimilation implications. Zhongguohua in Communist Party usage since the 1940s has implied not just assimilating Marxism to a Chinese cultural sphere, as the term "sinicisation" does, but also transforming China and Chinese culture in accordance with Marxism. As Bi and Xu state in their preface, the goal is both "to Zhongguohua Marxism and modernise (xiandaihua 现代化) Chinese philosophy," p. 1. The term should be understood dialectically. See, Arif Dirlik, "Mao Zedong and 'Chinese Marxism,"' op. cit.The proliferation of such work is the fruit of the Marxism Project initiated by the Party in 2004 under Hu Jintao's direction, which will be further discussed below. For this relationship, voiced by the head of the Propaganda Bureau, Li Changchun (李长春), see Mei Rongzheng, Makesizhuyi Zhongguohua, op. cit., p. 26.

39. Zhongguo gongchandang lishi, vol. 2, op. cit., p. 979.

40. Zhongguo gongchandang lishi (2011), op. cit., p. 502.

41. Guo Dehong, Zhongguo Makesizhuyi fazhan shi, op. cit., pp. 212-227. 
1980 repeatedly enjoined not to exaggerate Chairman Mao's shortcomings, and those whose disagreements may account for the nearly two decades it took to bring the recent Party History to its final form. The admission makes the Party and many Party leaders complicit in the leftist zeal that culminated in these deplorable events.

And yet, this is very much in line with the Party's intentions in choosing from a variety of representation of the past: not to condemn Mao and jeopardise the legitimacy the Party draws from the revolutionary past, but rather to provide "lessons" with which to guide the Party into the future. The account of Party history is replete with struggles against the "right" and the "left," more with the latter than with the former. The lessons of New Democracy are drawn out to stress the present day importance of the united front line, a mixed economy, respect for the past, etc. The Great Leap Forward provides the occasion for stressing the priority of the forces over the relations of production - in other words, class. The Cultural Revolution in its disorderliness provides proof of the centrality of unified Party leadership to national progress and welfare. It even had a bright side in preparing the Party for "socialism with Chinese characteristics" after 1978. The conclusions drawn in the texts after every major episode of Party history are not just summaries but also guides to the reading of the text and the correct "lesson" to be drawn from it.

The recently published history concludes with a chapter, "The great achievements and basic experiences of socialist revolution and construction led by the Party," that outlines the lessons to be drawn from the six decades of Party history covered in the text. The achievements range from finally unifying the country and bringing together the various nationalities to live in peace, to poverty alleviation, to the establishment of foreign relations and national defence to secure the safety of the nation. Of the lessons to be drawn from the experience, the centrality of economic development and advancing the forces of production take top priority. There is a reminder that sovereignty and self-reliance are preconditions of opening up to the world. In either case, a stable and consolidated Party leadership remains the guarantee for the country's future. ${ }^{(42)}$

\section{A spectral presence: Mao and the Party}

Mao Zedong leads a double existence in post-revolutionary China. Mao the individual remains a national icon for the role he played in national liberation and consolidation. This is the most widely shared image of Mao. In the official line, he is portrayed as the representative of the collective leadership that achieved the victory of the New Democratic revolution in 1949, and initiated the transition to socialism that was completed between 1952 and 1956. It is also the pervasive popular image of Mao propagated in popular consciousness through education and the popular media. ${ }^{(43)}$ It is likely that these days the majority of the population knows Mao mostly by the endless series of TV movies on the national revolution and the Anti-Japanese War in which Mao figures prominently.

There is also the Mao who was responsible for the Cultural Revolution, who is apparently still controversial. In the official line since 1978, Mao has been held responsible for the Cultural Revolution, although it took 30 years for this responsibility to be spelled out in any detail. A decision was made under Deng Xiaoping not to repudiate Mao as Joseph Stalin had been repudiated in the Soviet Union in 1956, perhaps because Mao was more like a combination of V.I. Lenin and Stalin in stature, and could not be repudiated without irreparably damaging the revolution and the Party. The official line remains ambivalent in stressing the "good" sides of Mao even during the Cultural Revolution. Mao made serious leftist errors, but they were exacerbated by the behind-the-scenes machinations of the Jiang Qing and Lin Biao cliques. Mao was not above recognising and trying to rectify his errors. He played some part in the progress during those years in the economy, technology, and foreign relations, in addition to producing theoretical documents of lasting value. The Party has been quick to suppress any expression of excessive zeal for Mao and his policies, but it also has been cautious in condemning Mao, even as it has reversed his radical policies. Even more so than in the popular celebrations of Mao referred to above, this ambivalence has been apparent in renewed experiments with "redness," among which the so-called Chongqing Model by the "princeling" Bo Xilai is the most prominent (see fn. 45).

Rather than repudiate Mao, the current interpretation seeks to appropriate his image for its own "socialism with Chinese characteristics." This is apparent in two important ways. One is the historical linkage between New Democracy and "socialism with Chinese characteristics" that was foregrounded with the bracketing of the Cultural Revolution as an episode in socialist development. The other is the institutionalisation of Mao Zedong Thought. In official ideology Mao Zedong Thought occupies a crucial role as the fountainhead of "Chinese Marxism."

Interestingly, since Mao Zedong Thought emerged in the midst of the New Democratic revolution, it bears upon it the stamp of both the policies and the theoretical achievements of that phase of the revolution. I have referred above to what these policies generally implied, and how the considerations that had given rise to them would also provide the reform leadership with its initial inspiration. That they were now premised upon a post-socialist situation called for further elaboration of Mao Zedong Thought in keeping with the times. According to the current interpretation, there have been two important periods in the making of Chinese Marxism: the New Democracy period and "socialism with Chinese characteristics," which represented another "revolutionary great leap" in making Marxism Chinese. The Mao Zedong Thought the Party restored in 1978 returned it to its "true" spirit, that of New Democracy, premised upon class alliance (united front) and development of the forces of production as the primary goals. This was the Mao legacy Deng Xiaoping drew upon to formulate "socialism with Chinese characteristics." One work writes more strongly that "Deng Xiaoping theory was nourished within the womb of Mao Zedong Thought" (yunyu yu Mao Zedong sixiang zhong 孕育于毛 泽东思想中). ${ }^{(44)}$

The appropriation of Mao for the reforms was a much more astute move than repudiating Mao Zedong Thought. According to Maurice Meisner, the Eighth Party Congress in 1956 presided over by Liu Shaoqi (刘少奇) and Deng Xiaoping had deleted "the phrase 'guided by the thought of Mao Tsetung"' from the new party constitution in order "to reinforce the new prin-

42. Zhongguo gongchandang lishi (2011), op. cit., pp. 1062-1069.

43. See, for instance, the high school texts for required courses published by the Ministry of Education, volumes 3 and 4, dealing respectively with history (Lishi 历史) and world personages (Zhongwai lishi renwu pingshuo 中外历史人物评说), pp. 82-85 and 96-103 respectively, Beijing, People's Education Press, 2010

44. Song Shichang and Nong Fang. Makesizhuyi Zhongguohua tonglun, vol. 1, op. cit., p. 19. It is difficult to say if there is an analogy here to what Marx had to say about the dialectics of one mode of production growing out of another. If there is, it would suggest that Deng Xiaoping Theory was a product but also a negation of Mao Zedong Thought, which would make more sense in terms of a non-dialectical reading of the discourse as product of Mao Zedong Thought but negation of the Mao elements in it. 

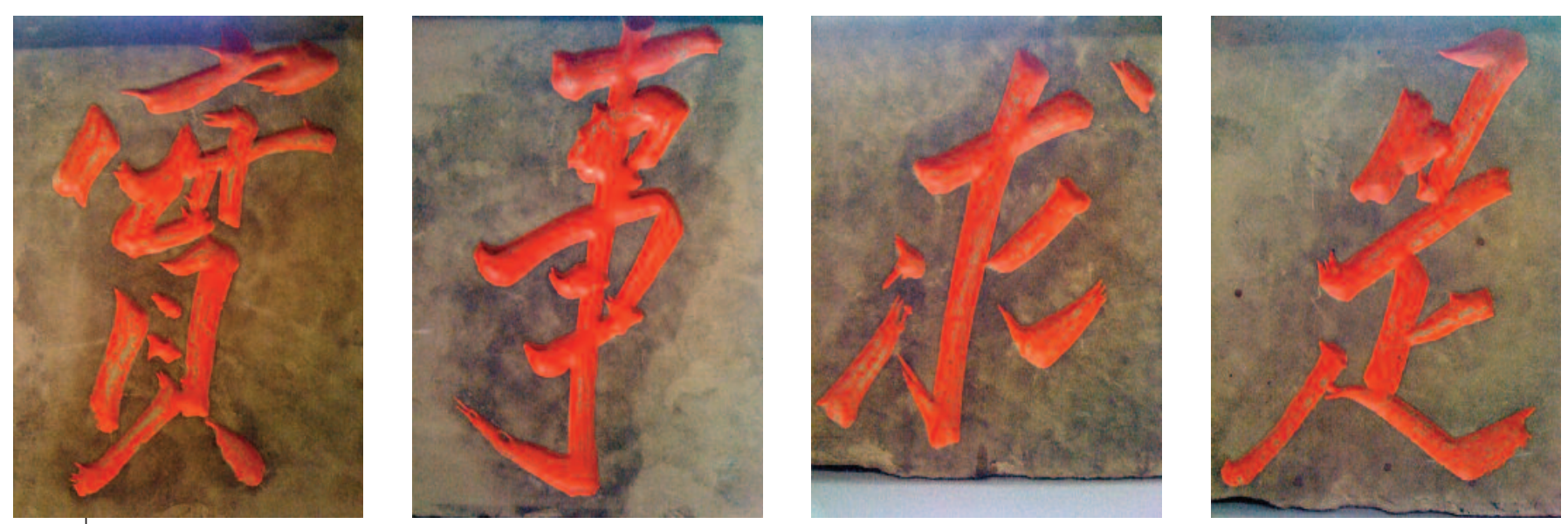

Mao quote in four parts in Mao's hand from the revolutionary museum at Yan'an (延安革命纪念馆): Shi Shi Qiu Shi. (c) G.R. Barmé

ciple of collective leadership." (45) The deletion had been viewed by cultural revolutionaries subsequently as further evidence of Deng Xiaoping's underhanded opposition to Mao. This time around, Deng recruited Mao for the reforms, while alleviating the anxieties of those within and without the Party who continued to be loyal to the revolution Mao had represented. More to the point here, by claiming Mao for his innovations, Deng incorporated Mao into his theory, which has since been passed down to "the important thought of 'three represents'" and "the scientific outlook on development."

In other words, New Democracy was one phase in the formulation of Chinese Marxism, but this first phase has been both a foundation and a paradigm for its subsequent development. ${ }^{(46)}$ These are the two temporalities of Mao Zedong Thought: one that relegates it to the past, as an expression of New Democracy that now has been superseded; the other a long-term reference for Chinese Marxism. In this perspective, there is hardly anything ideologically radical about the recent call by the prominent Party intellectual (and another "princeling") Zhang Musheng (张木生) to return to the social and political policies of New Democracy to resolve contemporary problems of development. At the same time, if there is an affinity between New Democracy and "socialism with Chinese characteristics," as the leadership has claimed, it is unlikely that New Democracy would resolve problems presented by a developmental trajectory of its inspiration. Indeed, as I observed above, ignoring the part contradictions created by New Democracy may have played in the radical turn of the mid-fifties is a significant shortcoming of Party histories anxious to represent the Cultural Revolution as an irresponsible deviation. (47)

Similarly, in discussions of Chinese Marxism Party leaders continue to reference Mao for their theoretical and policy innovations. A vague but potentially quite significant development in recent discussions of Chinese Marxism is their self-referentiality. Recently published studies of Chinese Marxism read mostly as histories of policy innovations by successive generations of Communist leaders that are now endowed with theoretical status in the formulation of a Chinese Marxism. There is little visible concern in these texts for theoretical discussions that critically engage issues of Marxist theory with reference to Deng Xiaoping's theory, "the important thought of 'Three Represents,"' or "the scientific outlook on development." Rather, each references predecessors in its ancestral lineage, "building" on them to further develop Chinese Marxism and Mao Zedong Thought. Mao's theoretical corpus from New Democracy days, and even some produced after his left deviation, are part of the theoretical corpus of the Party.

Theory itself endlessly changes in response to the times and national needs. In the words of $\mathrm{Hu}$ jintao in his ninetieth anniversary speech to the Party:

The development of practice, cognition of the truth, and innovation of theories know no boundary. The practice of the Party and the people keeps progressing, so should the theories guiding it. The path of socialism with

45. Maurice Meisner, Mao's China: A History of the People's Republic, New York, The Free Press, 1977, p. 182. This was in the midst of the criticism of Joseph Stalin and hero worship in the Soviet Union, and conflicts within the Chinese Communist Party over agrarian reform policies. It is also indicative of the intimate link between Mao Zedong Thought and Mao's thought that defies efforts to depersonalise the former.

46. Mei Rongzheng, Makesizhuyi Zhongguohua shi, op. cit., pp. 4-5.

47. The reference here is to Zhang Musheng, Gaizao womende wenhua lishi guan (改造我门的文化 历史观 Reforming our cultural historical outlook), Beijing, Military Science Publications, 2011. For the stir created by the book's call to New Democracy, see, David Bandurski, "Turning back to 'New Democracy'?", China Media Project, posted 19 May 2011, http://cmp.hku.hk/2011/05/ 19/12486/ (consulted on 30 April 2012); and Chris Buckley, "Exclusive: Party insider maps bold path for China's next leaders," Reuters.com, 18 August 2011, http://www.reuters.com/assets/ print?aid=USTRE77H11R20110818 (consulted on 30 April 2012). See also the interview with Zhang, "Zhang Musheng: Zai ju xinminzhuzhuyi daqi" (张木生:再举新民主主义大旗 Once again raise the great banner of New Democracy), Southern News Network, 31 October 2011, 9 pp., http://nf.nfdaily.cn/nfrwzk/content/2011-10/31/content_32350892.htm (consulted on 30 April 2012). Zhang is firmly committed to Communist Party leadership, advocates intra-Party democracy, and greater democratisation of politics with an emphasis on home-grown democracy, which he argues is to be found in New Democracy. It seems to me that the controversial aspect of Zhang's ideas may be due not to his advocacy of New Democracy as such but to a version of the latter that stresses the revolutionary spirit of "the Yan'an Way" against the reigning Party "orthodoxy" preoccupied with the development of the forces of production, its call for the Party to reground itself in the worker and peasant classes, its criticism of inequality, its condemnation of the Party for having turned away from these principles of New Democracy beginning in the 1990s (corresponding to the Jiang Zemin leadership, which brought capitalists into the Party), and its advocacy of contentious politics. These issues are also entangled in conflicts among Party "princelings" (the descendants of prominent revolutionaries) as well as between the "princelings" and those who have worked their way up from the bottom. Indeed, the Chongqing experiment and Zhang's call for a return to New Democracy may be viewed as variant responses to the same problems, the one advocating a greater role for the public in politics, the other re-politicisation under Party leadership with closer attention to socially equitable development. Despite its Cultural Revolutionary appearance, the Chongqing experiment would seem to be a highly controlled affair to avoid the dreaded chaos stirred up by the former. Zhang Musheng, who expresses a preference for the terms "Chongqing exploration" (重庆探索) or "Chongqing road" (重庆之路) over "Chongqing Model," notes its affinity to cultural practices in Yan'an ("Interview," p. 8). It also has affinities to New Democracy, and through it, to developmental ideas going back to Sun Yat-sen in its emphases in using capitalism for socialist ends, the priority it gives to people's livelihood, and public ownership of land as a developmental resource. See Philip C. C. Huang, "Chongqing: Equitable Development Driven by a 'Third Hand,'" Modern China, vol. 37, no. 6, 2011, pp. 569622. This experiment is currently in jeopardy due to a still unclear split in its leadership. For the revival of the Yan'an Way, see Geremie R. Barme, "The Children of Yan'an: New Words of Warning to a Prosperous Age," China Heritage Quarterly, no. 26, June 2011, http://www.chinaheritagequarterly.org/features.php? searchterm=026_yanan.inc\&issue $=026$ (consulted on 30 April 2012). 
Chinese characteristics will definitely be expanded through the innovative practice of the Party and the people, and the system of socialism with Chinese characteristics will surely continue to improve as we deepen reform and open up wider. This process will certainly open up broad prospects for theoretical innovation. In upholding Marxism under the new historical conditions, it is important to promptly address new issues emerging in practice and thus provide scientific guidance for practice. We should have a correct understanding of the global development trend and China's basic condition of being in the primary stage of socialism, find out more about the features of China's development at the current stage, review the new experience gained in a timely manner by the people led by the Party, and create new theories with the focus on major issues concerning economic and social development, so as to ensure the vitality of scientific theories. ${ }^{(48)}$

This endless development of theory in response to the changing needs of practice suggests that theory no longer serves as a check on, or even guide to, future developments, which are to be determined solely by their efficacy in securing the developmental goals of the regime. It is not that there is no longer any concern for Marxism; on the contrary, the Party repeatedly stresses its loyalty to the essence of Marxism as the thread that runs through the development of Chinese Marxism. Official publications express considerable concern over ignorance of Marxism, indifference to it for no longer being relevant, or feigning interest while undermining it, clearly referring above all to Party cadres. ${ }^{(49)} \mathrm{Hu}$ Jintao was responsible for initiating in 2004 a "Marxism project" (Makesizhuyi gongcheng 马克思主义工程) intended to produce an interpretation of Marxist classics appropriate to contemporary circumstances. One of the basic goals of the project was to provide theoretical, historical, and educational material that would give coherence to Party policies and revitalise the study of Marxism - Chinese Marxism. ${ }^{(50)}$

The project is important for understanding the regime's attitude toward Marxism and Mao's place in it. The primary purpose of the project was to establish an unfolding Chinese Marxism on firmer theoretical ground by uncovering in the Marxist classics evidence that Marx and Engels at least in theory had anticipated developments in Chinese socialism; in other words, by articulating texts to policies that had guided the course the Chinese revolution had taken, as well as the policies of the leadership of "socialism with Chinese characteristics" from Deng through Jiang to Hu. As the authors of Zhongguo Makesizhuyi fazhan shi write, "The only Chinese Marxism is Marxism that has been integrated with Chinese realities. Only by answering to the needs of the Chinese revolution and reconstruction can Chinese Marxism take shape and advance." (51)

This is a theme that in a basic way runs through the corpus of Mao Zedong Thought, from Mao during New Democracy to Hu Jintao as the most recent representative of "socialism with Chinese characteristics." What is new about it is ruling out or downgrading certain fundamental features of Marxist theory - notably class analysis - from any consideration in the formation of Chinese Marxism. The issue of class is dismissed as having been exaggerated in the days of New Democracy, abused during the Cultural Revolution, and irrelevant under the socialist regime. While vigilance is called for against both the "right" and the "left," it is the "left" that represents the more important threat to the Party's policies and the country's security and welfare. ${ }^{(52)}$ The problem is that leaving out those aspects of Marxist theory that contradict the regime's policies obviates the need to engage Marxist theory in its wholeness, and suffers from the same tendentiousness in the reading of theory as its Cultural Revolution predecessors. Sweeping aside the issue of class also glosses over the contradictions of New Democracy that produced the conflicts of the 1950s, and the contradictions that mark Chinese society today. Marxism is obviously too important for the regime's legitimacy to be simply cast aside. It is nevertheless instrumentalised in the service of policies that accommodate capitalism, which is in the process of transforming Chinese society - and not in any direction recognisable as socialism. What the future may bring is another matter, of course, but then judging by what the regime says, Marxism in the future may serve any and all policies that suit the needs of China as the regime perceives them. The gap between promise and reality may be an important reason that many in and out of China remain sceptical of the regime's Marxism or socialist commitments.

On the other hand, the claims to Marxism need to be taken seriously for what they suggest. Chinese Marxism is a Marxism that is rooted in the Marxist tradition going back to Marx and Engels - "ancestors" (laozuzong 老祖宗), as Deng Xiaoping described them. ${ }^{(53)}$ But it is also Marxism that has been integrated with Chinese circumstances in keeping with the history of Marxism, which has taken national form everywhere. And as the circumstances change, so does the synthesis of theory and practice. What is implied here is that Marxism is a work in progress and needs to be re-invented on an ongoing basis if it is not to degenerate into dogma. ${ }^{(54)}$ It is not a matter of following texts, but of creating new Marxisms out of them. Hence the insistence in the new texts on Chinese Marxism that both New Democracy and "socialism with Chinese characteristics" opened new eras in the unfolding of Marxism. They are most relevant to China, but they have implications for other societies as well at a time when socialism is in retreat.

Two considerations guide the project. First, however fundamental the principles and methods of Marxism, Marx and Engels could not have foretold the course socialism would take once it had been established. Secondly, theoretical development to answer to contemporary needs can no longer rely on the mediation of Soviet interpretations, as in the past, but requires independent investigation of the texts. ${ }^{(55)}$ The investigation of texts has been international in scope as Chinese researchers comb libraries for Marxist texts, in some ways assuming leadership in such research. There is a suggestion in some discussions that the project of making Marxism Chinese has assumed an even broader scope than earlier. One text points to four dimensions to making Marxism Chinese: "concretisation" (jutihua 具体化) of theory, "nationalisation" (minzuhua民族化) of its form, "modernisation" (xiandaihua 现代化) of the classics, and "practicalisation" (shijianhua 实践化)

48. Hu, "Speech at CPC Anniversary Gathering," op. cit., p. 6.

49. Guo Dehong, Zhongguo Makesizhuyi fazhan shi, op. cit., p. 382.

50. Xiao Dongbo and NieYueyan, Zhongguo gongchandang lilun jianshe de lishi jingyan yanjiu, op. cit., pp. 228-231. See also, "Makesizhuyi gongcheng jiaocai meibenzhi shaotouru liangbaiwan yuan”(马克思主义工程教材每本至少投入两百万元 At least 2 million yuan to be spent on each volume of the teaching materials of the Marxism project), Liaowang dongfang zhoukan, 26 October 2004. Author's personal collection. I am grateful to the Central Compilation and Translation Bureau (Zhongyangbianyiju 中央编译局), especially its vice-director, Dr. Yu Keping (俞可平 ), for making materials on the project available to me while I was a visiting scholar there in 2006.

51. Guo Dehong, Zhongguo Makesizhuyi fazhan shi, op cit., p. 381,

52. Ibid., pp. 384-385

53. Ibid., p. 383

54. The preferred term is "innovate" (chuangxin 创新), which has become a very popular term in the Party lexicon, especially since jiang Zemin.

55. Interview with Yang Jinhai (杨金海), Deputy Secretary of the Central Compilation and Translation Bureau, August 2006. Yang has been one of the foremost interpreters of the philosophical basis of Hu Jintao's "Scientific Outlook on Development." See also, Yang Jinhai, "Makesizhuyi jingdian zhuzuo yanjiu de xianzhuang he weilai" (马克思主义经典著作研究的现状和未来 The contemporary condition and the future of studies of Marxist classics). Unpublished discussion paper. I am grateful to Yang Jinhai for providing me with these materials. 
of its theoretical form. ${ }^{(56)}$ Especially significant is the modernisation of the classics.

Whether or not these new departures point to aspirations to leadership in global Marxism commensurate with the regime's newfound power in the world as the foremost success story of socialism, or better still as a socialist version of capitalism, there is not much question about the immediate goals of refurbishing Chinese Marxism theoretically and giving it canonical status. What is less obvious but even more significant is that it is the Chinese present - the standpoint of an unfolding Chinese Marxism - that provides the guide to reading the classics and, in a manner of speaking, re-theorising the theory. What will be left of Marxism by the time they are finished remains to be seen. Mao's successors have arguably gone beyond anything he claimed in making theory their own, subservient to the practices of national development within a context of global capitalism. Ironically, the more they change Marxism to respond to contemporary circumstances, the less connected they seem to an environment in which Marxism carries little weight among the population at large. But they may legitimately claim, as they do, that they are following the example of the Chairman - both in making Marxism Chinese and in silencing critics from the left who would suggest that the more the theory becomes "Chinese," the less there is left of it that may be viewed as Marxist in any serious sense of that term. ${ }^{(57)}$

\section{Conclusion}

Mao has both an ancestral and a phantom existence in texts on Party history and Chinese Marxism. Like Marx, Engels, and Lenin before him, he is an ancestor to the present, and a source of valuable lessons and principles to draw upon as necessary or appropriate. As the founding ancestor of Chinese
Marxism, he commands an even greater immediacy than Marx and Engels as an example in rendering theory meaningful for practice. On the other hand, it is obviously no easy task to de-personalise Mao Zedong Thought, or to safely retire Mao's policies to a receding past while upholding the "thought" named after him as an exemplary principle of theorising the Party's changing practice. Continued uncertainty over the future - whether in calls for a return to New Democracy or renewed experiments with "redness," among others - seems inevitably to play out on a discursive terrain in which Mao is ever present in one form or another. In its very appropriation by the Party, Mao Zedong Thought guarantees to Mao and Maoism a phantom existence that is imminent in Chinese socialism, both in its achievements and its anxieties.

I Arif Dirlik most recently served as the 1922 Rajni Kothari Chair in Democracy, Centre for the Study of Developing Societies, New Delhi. His most recent book-length publications are Culture and History in Post-revolutionary China, and two edited volumes, Sociology and Anthropology in Twentieth Century China and Global Capitalism and the Future of Agrarian Society.
56. Song Shichang and Nong Fang, Makesizhuyi Zhongguohua tonglun, vol. 1, op. cit., pp. 2-3.

57. This applies even to Party elders critical of the turn Marxism has taken under the regime: "In July 2007, even the 'Maoflag' Website was temporarily shut down when it posted an open letter by seventeen former high-level CCP officials and Marxist academics accusing CCP policies of making a mockery of Marxism and taking the country 'down an evil road."' Zhao, "Sustaining and Contesting Revolutionary Legacies in Media and Ideology," p. 228. Party elders, who seem to wait until retirement to go public with their criticisms, are routinely censored regardless of the nature of their criticism. This includes Premier Wen Jiabao, who has not waited until retirement to go public. For a more recent general shut-down of "leftist" sites, see, Keith B. Richburg, "China shuts leftist Web sites as political strife continues," Washington Post, Friday, 6 April 2012, http://www.washingtonpost.com/world/china-shuts-leftist-web-sites-as-political-strife-continues/2012/04/06/glQAnJLUzS_story.html (consulted on 8 May 2012). For an interesting theoretical discussion of continuities with Maoist language that currently have different consequences for communication with the people than they did earlier, see Maurizio Marinelli,"The Historicity Beyond the Appearance of Words: The Treachery of Images in Chinese Political Language," conference paper, www.hichumanities.org/AHproceedings/Maurizio\%20Marinelli.pdf (consulted on 30 April 2012). 